\title{
ECONOMIC EFFICIENCY OF RESOURCE-SAVING TECHNOLOGIES AND COTTON YIELD OF ANDIJAN-36 VARIETY
}

\author{
Mamura Sadirdin kizi Atabayeva \\ Doctor of Philosophy on Agricultural Sciences, Senior Teacher of the Department of Plant Science, \\ Andijan Branch of Tashkent State Agrarian University, Kuyganyor-160700, Andijan, Uzbekistan. \\ Mukimjon Yakubjonovich Juraev \\ Independent Researcher, Department of Plant Science, \\ Andijan Branch of Tashkent State Agrarian University, Kuyganyor-160700, Andijan, Uzbekistan. \\ Ikboljon Kobiljon ugli Nosirov \\ Independent Researcher, Department of Plant Science, \\ Andijan Branch of Tashkent State Agrarian University, Kuyganyor-160700, Andijan, Uzbekistan.
}

DOI: https://doi.org/10.36713/epra3815

\begin{abstract}
With the use of resource-saving agro-technology and processing with a new combination aggregate in autumn, cotton yield of 37.9-40.4 c/ha was obtained from the variants where the $50 \%$ annual rate of $200 \mathrm{~kg} / \mathrm{ha}$ norm of nitrogen was applied in the form of liquid ammonia under the ridges and the remaining $50 \%$ of liquid ammonia was used during the growing period of cotton plant in the form of ammonium salt petre by stratification. In these variants cotton seeds were sown in single-row and double-row methods. They produced additional yield of 4.1-5.9 c/ha compared to the control variants and the highest economic efficacy was achieved. Net profit from these variants constituted 2079,1-2793.7 thousand sums, profitability rate was 52.3-68.4\%, in comparison with control variants, the net profit was 1127,7-1569,3 thousand sums more while the profitability rate was $29,1 \%$. - 38.8\% higher.
\end{abstract}

KEYWORDS: Soil, cotton plant, single-row and double-row, cotton productivity, new combination technology, Andijan-36 variety, liquid ammonia, net profit.

\section{INTRODUCTION}

In the world practice, the minimum soil tillage and crop cultivation are currently implemented in more than 100 million hectare areas. The combination system of soil tillage encompass many measures. This method is effective in the soils with different fertility, especially, in manure areas (when NPK balance is high). Minimum soil processing compared to traditional technologies is not only energy-resource-saving technology but also soilprotecting technology too. In soil tillage technology the techniques are widely used that can be perform several operations simultaneously. Minimal tillage is widely used in Canada, USA, Germany, Russia, India, Australia and other countries.

Combined techniques in minimal soil tillage allow to maintain soil fertility, prevent soil compaction, reduce erosion processes, and ensure food security through obtaining precocious, high-quality yields using scientifically assured technology of the effective use of mineral fertilizers. Therefore, one of the main tasks of today is to develop the use of energy-saving technologies and techniques for soil protection in the cultivation of cotton plant and the crops of its complex by the minimal tillage of soil. 
It is well-known that the productivity and fiber quality of each cotton variety depends, first of all, on how we follow to the scientifically proven, high-quality modern agrotechnics and perform timely agrotechnical activities, taking into account their biological characteristics. In the researches conducted by A. Ochirov, G. Muchkaeva, and N. Bavaev [9] at Kalmykia State University, the resource-saving agrotechnology was used for soil processing and achieved 2-2.5 times less cost of fuel and $30-40 \%$ of decreased costs compared to the variant where the simple tillage was used in the cultivation of winter wheat crop, while in the researches carried out by A.K Kashkarov, T.Z. Fayziev [3] it was determined that there was possibility to obtain $3,7 \mathrm{c} /$ ha additional yield of cotton due to proper weight of soil in the ridges for cotton, fast germination of seeds under high temperature, rapid growth and development of cotton plant and 4-5 days earlier maturation of cotton yield in comparison with conventional flat fields. On the base of the results of many years of scientific research by S.N Ryjov, V.P Kondratyuk and Yu.A. Pogosov [10], the application of the method of sowing seeds in early spring in the ridges prepared in autumn, complete germination of seeds and consequently, producing high yields of cotton, as well as, economic efficiency of this method were scientifically and practically proven.

As S.Yusupov, A.Khaydarov, T.Komilov [14] have emphasized, the density of seedlings of Andijan-33 cotton variety in the schemes $90 \times 10-1$ and $90 \times 10-1-2$ was 111 - 165 thousand pieces in light virgin soils of Andijan region, mineral fertilizers were applied in the norm of NPK-250-175-125 kgs per ha, cultivated cotton yield made $37,8 \mathrm{c}$ per ha and compared to control variant 3,2 c/ha additional yield was obtained.

S.Bakhromov, U.Mukaramov [1], K.M.Tojiyev [12], A.Khaydarov, K.Kirgizboyev [5], Sh.T.Salomov
[11], S.T.Negmatova [8], S.Ubaydullayeva [13] conducted scientific researches on the rational utilization of labor, land-water resources and energy, developing different technologies of producing economically efficient, cheap and qualitative products.

In their research Khasanova F.M, Khasanov M.M, Atabayeva M.S [4] observed that in comparison with the pre-processing condition, the soil porosity increased up to $1,7-2,2 \%$ by the layers relatively to the density of seedlings, while compared to the $1^{\text {st }} 2^{\text {nd }}$ variants it raised to $0,4-0,5 \%$ in the variants where the soil was processed with combination aggregate in $30-35 \mathrm{~cm}$ depth in autumn applying nitrogen in the form of liquid ammonia and in the norm of $100 \mathrm{~kg} /$ ha simultaneously making ridges for seeds and also using $100 \mathrm{~kg} / \mathrm{ha}$ nitrogen in the form of ammonium saltpetre during the active period of cotton plant.

\section{MATERIALS AND METHODS}

The investigations of the research were conducted under the given order in 2015-2017 on the farm "Davr hamkorligi" in Kurgantepa district of Andijan region. Experimental field was old irrigated land with light virgin soil and its content was moderate sandy loam, groundwater was in 4,0-5,0 m depth. Soil solution alkalineness was $\mathrm{pH}$ 7-7,4; Humus and gross nitrogen amount were $0.8-0.9$ and $0.05-0.09 \%$, respectively.

The experimental variants were in three repetitions, in one plot where each variant contained 8 rows with a total area of $720 \mathrm{~m}^{2}$ and a calculated area of $360 \mathrm{~m}^{2}$.

The accuracy of the yields obtained from the experimental variants and repetitions was analyzed by dispersion method [2]. For the study of agrochemical [6] and agrophysical properties [7] of experimental field soils the conventional methods were used.

Table 1

Experiment system

\begin{tabular}{|l|l|c|c|}
\hline \multirow{2}{*}{ № } & \multicolumn{1}{|c|}{ The method of soil processing } & Sowing method & $\begin{array}{c}\text { Density of } \\
\text { theoretical } \\
\text { seedlings }\end{array}$ \\
\hline $\mathbf{1}$ & Tilling with plough in 30-35 cm depth (control) & $90 \times 10-1$ & $90-100$ \\
\cline { 3 - 4 } & \multicolumn{1}{|l|}{$\begin{array}{l}\text { Processing with new combination aggregate in 30-35 } \\
\text { cm depth, and then making ridges (in autumn) }\end{array}$} & $90 \times(30 \times 12)-1$ & $140-150$ \\
\hline \multirow{2}{*}{$\mathbf{3}$} & $\begin{array}{l}\text { Processing with new combination aggregate in 30-35 } \\
\text { cm depth and then making ridges }\end{array}$ & $90 \times 130 \times 12)-1$ & $90-100$ \\
\cline { 2 - 4 } & & $90 \times 10-1$ & $90-150$ \\
\hline
\end{tabular}

Comments: In the $1^{\text {st }}-2^{\text {nd }}$ variants the land was tilled by conventional method in $30-35 \mathrm{~cm}$ depth and made ridges in 30-35 cm height, annual norm of mineral fertilizers was $N P K-200-140-100 \mathrm{~kg} / \mathrm{ha}$.

N-nitrogen; P-phosphorus; K-potassium.

The experiments were carried out during the years 2015-2017 on the base of agreed experiment system.

In the variants 3-4 the soil was processed with a new combined aggregate, ridges at a height of $30-35 \mathrm{~cm}$ were prepared, and the mineral fertilizer nitrogen was applied under $30-35 \mathrm{~cm}$ depth of ridges in the norm of $200 \mathrm{~kg} / \mathrm{ha}$ of liquid ammonia and also $P-140-100 \mathrm{~kg} / \mathrm{ha}$.

In the $5^{\text {th }}-6^{\text {th }}$ variants the soil was processed with the help of new combination aggregate, ridges were made in $30-35 \mathrm{~cm}$ height, under these ridges mineral fertilizer nitrogen was applied in 30-35 $\mathrm{cm}$ depth in the form of liquid ammonia from $100 \mathrm{~kg} / \mathrm{ha}$ annual rate, the remaining $100 \mathrm{~kg} / \mathrm{ha}$ fertilizer was used in the form of ammonium saltpetre, $P K-140-100 \mathrm{~kg} / \mathrm{ha}$ during the active period of cotton plant.

On these problems, field experiments were conducted to study the effect of the application time of nitrogen fertilizer in the form of ammonia on the cotton yield of Andijan-36 cotton plant variety in new combined technology of tillage in 2015-2017. 


\section{RESULTS AND DISCUSSION}

In our research, we studied the productivity of cotton plant under the effect of the use of traditional soil processing and resource-saving agrotechnologies in the fields where the cotton seeds were sown in single and double-rows, used nitrogen fertilizers in the form of liquid ammonium and ammonium saltpetre by comparing these two methods.

In our experience, the favorable soil conditions in the variants where the new soil tilling technology was used, have allowed more acceleration of germination of Andijan-36 cotton variety seeds by $25-30 \%$ compared to the simple variant in which the soil was processed in 30 $35 \mathrm{~cm}$ depth and then made ridges, as well as, seeds have germinated 3-5 days earlier. As a result, the growth and development of cotton in these variants accelerated, allowing the production of early and high quality cotton.

In our research it was determined that the use of resource-saving agrotechnologies had a positive impact on the growth and development of cotton, that is, with the use of combined aggregate in the fall simultaneously applying $100 \mathrm{kgs}$ of nitrogen in the form of liquid ammonia under the ridges and $100 \mathrm{~kg}$ of ammonium saltpetre during active period of cotton plant in the variants where seed sowing was done under the scheme 90x10-1 the number of unripe bolls was $7.1 ; 10.9$ pieces, similarly, in the variants which had the same method and mineral fertilizers rate, only with different planting system of $90 \times(30 \times 12)-1$, cotton bolls were 5,0; 8.9 pieces. With respect to control variant, it was identified that according to time and planting systems, these indications increased by $0.8-2.8 ; 0.4-1.7$ pieces. In the cultivation of Andijan-36 cotton plant variety after the application of resource-saving agro-technologies to the soil, i.e, processing the soil with new combination aggregates and simultaneously adding the nitrogen of 100 and 50 percent from $200 \mathrm{~kg} / \mathrm{ha}$ annual norm in the form of liquid ammonia under the ridges, sowing the seeds in the ridges by single-row and double-row method average 36,2 and 39,2; 37,9 and 40,4 c/ha cotton yield was produced in the variants 3-4 and 5-6 within 3 years, compared to the variants grown traditionally 4,1-5,6 c/ha additional cotton yield was produced.

Additional cotton yield of 3,2 and 3,4 c/ha was obtained in the $4^{\text {th }}-6^{\text {th }}$ variants in which the soil was processed with the help of combination aggregate in autumn, applying 100 and 50 percent amount of nitrogen of annual rate $200 \mathrm{~kg} / \mathrm{ha}$ under the ridges in the form of liquid ammonium, and seeds were sown in the ridges by double-row sowing method. A reasonable difference wasn't observed in both ammonium rates.

Thus, it was identified that the use of a new soil treatment aggregate in autumn applying at the same time the nitrogen of $50 \%$ under the ridges in the form of liquid ammonium from its $200 \mathrm{~kg} / \mathrm{ha}$ annual norm and other $50 \%$ in the form of ammonium saltpeter during the growth period and stratification nutrition resulted positively.

In the variants 5-6 where the soil was processed with resource-saving agro-technologies, using a new soil treatment combination aggregate in autumn applying at the same time the nitrogen of $50 \%$ under the ridges in the form of liquid ammonium from its 200 $\mathrm{kg} / \mathrm{ha}$ annual norm and other $50 \%$ in the form of ammonium saltpetre during the growth period and performed stratification nutrition cotton productivity of Andijan-36 variety constituted 37,9-40,4 c/ha, compared to the variants in which the nitrogen was used in the form of liquid ammonia from $200 \mathrm{kgs}$ annual norm, it was 1,7-2,2 c/ha more.

It is important to evaluate economically the effectiveness of each agro-measure tested in the experiments in order to determine a particular level of useful or highly effective results and to introduce them into production.

Gross income and net profit were calculated based on the average costs of 3 years related to experimental variants. Accordingly, the profitability of variants was calculated. 
Table 2

The influence of agro-measures on the productivity of Andijan-36 cotton plant, centner/hectare, (in 2015-2017) average 3 years

\begin{tabular}{|c|c|c|c|c|c|c|c|}
\hline № & The method of soil processing & Sowing scheme & $\begin{array}{c}\text { in } \\
2015\end{array}$ & $\begin{array}{l}\text { in } \\
2016\end{array}$ & $\begin{array}{c}\text { in } \\
2017\end{array}$ & $\begin{array}{l}\text { Average } \\
3 \text { years }\end{array}$ & $\begin{array}{l}\text { Additional } \\
\text { yield } \\
\text { compared to } \\
\text { control, c/ha }\end{array}$ \\
\hline 1 & \multirow{2}{*}{$\begin{array}{c}\text { Tilling with plough in 30-35 cm depth } \\
\text { (control) } \\
\text { NPK 200; 140:100 }\end{array}$} & $90 \times 10-1$ & 34,1 & 33,2 & 34,1 & 33,8 & \\
\hline 2 & & $90 \times(30 \times 12)-1$ & 34,9 & 33,9 & 34,6 & 34,8 & \\
\hline 3 & \multirow{2}{*}{$\begin{array}{l}\text { Processing with new combination } \\
\text { aggregate in } 30-35 \mathrm{~cm} \text { depth, making } \\
\text { ridges (in autumn), liquid ammonia } \\
200+\text { PK 140:100 }\end{array}$} & $90 \times 10-1$ & 37,0 & 35,9 & 35,7 & 36,2 & 2,4 \\
\hline 4 & & $90 \times(30 \times 12)-1$ & 38,8 & 37,3 & 38,5 & 39,2 & 4,4 \\
\hline 5 & \multirow{2}{*}{$\begin{array}{c}\text { Processing with new combination } \\
\text { aggregate in } 30-35 \mathrm{~cm} \text { depth, making } \\
\text { ridges (in autumn), liquid ammonia } \\
100+\text { NPK 100; } 140: 100\end{array}$} & $90 \times 10-1$ & 39,4 & 37,0 & 37,3 & 37,9 & 4,1 \\
\hline 6 & & $90 \times(30 \times 12)-1$ & 40,7 & 39,2 & 41,3 & 40,4 & 5,6 \\
\hline \multicolumn{8}{|c|}{$\begin{array}{r}\text { In } 2015 \text { - Sd=0,19 c/ha; } \mathrm{HCP}_{05}=0,4 \mathrm{c} / \mathrm{ha} ; \mathrm{HCP}_{05}=1,07 \% ; \mathrm{Sd}=0,14 \mathrm{c} / \mathrm{ha} ; \mathrm{HCP}_{05}(\mathrm{~A})=0,2 \mathrm{c} \\
\mathrm{HCP}_{05}(\mathrm{~B})=0,23 \mathrm{c} / \mathrm{ha} ; \mathrm{HCP} 05=0,61 \%\end{array}$} \\
\hline \multicolumn{8}{|c|}{$\begin{array}{c}\text { In } 2016 \text { - Sd=0,38 c/ha; } \mathrm{HCP}_{05}=0,8 \mathrm{c} / \mathrm{ha} ; \mathrm{HCP}_{05}=2,22 \% ; \mathrm{Sd}=0,27 \mathrm{c} / \mathrm{ha} ; \mathrm{HCP}_{05}(\mathrm{~A})=0,57 \mathrm{c} / \mathrm{ha} ; \mathrm{HCP}_{05}=1,58 \% ; \mathrm{Sd}=0,22 \mathrm{c} / \mathrm{ha} ; \\
\mathrm{HCP}_{05}(\mathrm{~B})=0,46 \mathrm{c} / \mathrm{ha} ; \mathrm{HCP}_{05}=1,29 \%\end{array}$} \\
\hline \multicolumn{8}{|c|}{$\begin{array}{c}\text { In } 2017-\mathrm{Sd}=0,39 \text { c/ha; } \mathrm{HCP}_{05}=0,82 \mathrm{c} / \mathrm{ha} ; \mathrm{HCP}_{05}=2,23 \% ; \mathrm{Sd}=0,28 \mathrm{c} / \mathrm{ha} ; \mathrm{HCP} 05(\mathrm{~A})=0,59 \mathrm{c} / \mathrm{ha} ; \mathrm{HCP}_{05}=1,6 \% ; \mathrm{Sd}=0,23 \mathrm{c} / \mathrm{ha} ; \\
\mathrm{HCP}_{05}(\mathrm{~B})=0,48 \mathrm{c} / \mathrm{ha} ; \mathrm{HCP}_{05}=1,32 \%\end{array}$} \\
\hline
\end{tabular}

Moreover, the purchase price of raw cotton in 2015-2017 was calculated and the average 3-year figures are taken as a basis.

According to the three-year research, each of the variants under the influence of different agrotechnologies used in the experiments had specific economical indications considering particular costs and cotton productivity.

When the land was processed traditionally, that is, performing tillage in autumn, harrowing and other agrotechnical measures, following ridge preparation, and seeds were sown by single-row and double-row method in early spring, the productivity made $33,8-34,5 \mathrm{c} / \mathrm{ha}$, the profit from the sale of total cotton raw material constituted 5094,9-5373,2 thous.sums, total costs were $4143,4-4148,8$ thous.sums, net profit 951,4-1224,5 thous.sums, profitability rate was 23,2-29,6 percent.

In the areas where the soil was tilled with a new combination aggregate following the application of 100 $\%$ of nitrogen from $200 \mathrm{~kg} / \mathrm{ha}$ annual rate in the form of liquid ammonia and when the seeds of Andijan-36 cotton plant variety were sown by single-row and double-row method the productivity made 36,2-38,2 $\mathrm{c} /$ ha, profit from sale of total cotton raw material was 5746,1-6210,8 thous.sums, total costs were 3947,64065,1 thous.sums, net profit constituted 1798,5-2145,7 thous.sums, profitability rate was 46,2-52,2 percent. Compared to the $1^{\text {st }} 2^{\text {nd }}$ variants where the traditional tillage was used, aforementioned variants productivity was 23,0-22,6 percent higher.

Furthermore, in the variants (5-6) that the soil was processed with resource-saving agro-technologies, using a new soil treatment combination aggregate in autumn applying at the same time the nitrogen of $50 \%$ under the ridges in the form of liquid ammonium from its 200 $\mathrm{kg} / \mathrm{ha}$ annual norm and other $50 \%$ in the form of ammonium saltpetre during the growth period of
Andijan-36 variety with stratification nutrition cotton productivity of Andijan-36 variety with seed sowing by single-row and double-row method, cotton yield made $37,9-40,4 \mathrm{c} / \mathrm{ha}$, and additional 4,1-5,9 c/ha yield and the highest economical profit were obtained compared to control variants (1-2) where soil processing was done traditionally in 30-35 depth following ridge preparation. Net profit obtained from this variant has constituted 2079,1-2793,7 thous.sums, profitability rate was 52,368,4 percent and when compared to the variant in which the soil was processed with traditional method in 30-35 $\mathrm{cm}$ depth and then made ridges, the net profit made $1127,7-1569,3$ thous.sums more, while profitability made 29,1-38.8 percent higher.

To sum up, it was determined that in the variants with soil tillage by new combined aggregates, and application of $100 \%$ of nitrogen from $200 \mathrm{kgs}$ of annual rate in the form of liquid ammonia under the ridges in autumn, and while comparing to cared variant, application of $50 \%$ of nitrogen under the ridges in the form of liquid ammonia, that is, using $100 \mathrm{kgs}$ of nitrogen and the remaining $100 \mathrm{kgs}$ during the growing period of cotton plant by stratification, there is a possibility of cultivating early and high quality cotton yield because of favorable condition.

\section{CONCLUSION}

According to the results of research, the use of resource-saving agrotechnology in the cultivation of Andijan-36 cotton plant variety, i.e, processing with combinaned aggregate and simultaneously applying $50 \%$ of nitrogen of annual rate under the ridges in the form of liquid ammonia, the other 50 percent during growth period of cotton plant by stratification, sowing seeds by single-row and double-row method and consequently, resource-saving agrotechnology in cotton plant growing were found to be economically effective. 


\section{REFERENCES}

1. Bakhromov S., Mukaramov U. (1992). The influence of tillage depth on the plants of double cropping. Soil processing and crop rotation. International scientificpractical conference materials collection. Tashkent. pp. 814 .

2. Dospekhov B.A. (1985). Methodics of field experiments.M: Agropromizdat, $351 \mathrm{p}$.

3. Kashkarov A.K., Fayziyev T.Z. (1972). Ridge culture of cotton plant. Agriculture of Uzbekistan, №2. pp. 40-41.

4. Khasanov F.M, Khasanov M.M, Atabayeva M.S. (2019). The influence of combined soil processing and nitrogen fertilizer application on the productivity of cotton plant of Andijan-36 variety///Journal "Actual problems of today's science”. Moscow. №2. pp. 162-171.

5. Khaydarov A., Kirgizbayev K. (2008). The growth and development of cotton plant cultivated under the method of combined soil processing. Problems of farming: investigations and solutions. Fergana. pp. 52-53.

6. Methods of agrochemical studies of soil in Central Asia. Tashkent, edit. 4th. Amendment. UzSRChI, 1973, 132 p.

7. Methods of agrophysical studies of soil in Central Asia. Tashkent. UzSRChI, 1973, 135 p.

8. Negmatova $S$. (2015). The influence of deep inter-row treatment to cotton plant on water retention capability of soil. Agro ilm. №6. pp. 8-9.

9. Ochirov A.Yu., Muchkayeva G.M., Bavayev N.G. (2016). The ways for increasing capacity of aggregates in the application of resource-saving technologies. Materials of I International scientific-practical internet - conference "Actual ecological condition of eresources". Electronic collection of articles, February 29, s. Solenoye Zaymishe, pp. 1102-1106

10. Ryjov S.N., Kondratyuk V.P., Pogosev Yu.A. (1980). Cultivation of cotton plant in the ridges and beds. Tashkent, FAN. 76 p.

11. Salomov Sh.T. (2017). Improving the technology of main and inter-row soil processing// Abstract of dissertation for candidacy of the degree of doctor on agricultural sciences (DSc). Tashkent, PSUEAITI. 27 p.

12. Tojiyev K.M. (2007). The influence of cotton seed treating with different substances on the germination of shoots and cotton productivity// Scientific and practical basis of increasing soil fertility: The collection of articles from international scientific-practical conference. Tashkent.pp. 334-337

13. Ubaydullayev S. (2017). The influence of double-row seed sowing on germination dynamics of cotton seeds. Agro ilm. № 2. pp. 9-10.

14. Yusupov S., Khaydarov A. (2006). Agrotechnics for new varieties of cotton plant "Andijan-36" and "Andijan37”. Agriculture of Uzbekistan journal. Tashkent. №6. pp. 9. 